\title{
Pensar la pandemia: palabras que sirven
}

\author{
Laura Scarabelli \\ Università degli Studi di Mila
}

\section{Entrada: vivir con coronavirus}

Más allá de lo meramente anecdótico inscrito en las experiencias individuales de cada uno de nosotros durante estos largos meses de aislamiento social, es realmente complejo abordar una reflexión sobre lo que estamos viviendo, no tenemos suficiente distancia crítica, podemos tan solo imaginar el mundo que nos acogerá cuando salgamos de esta suspensión que nos envuelve. Muchas son las preguntas que nos asedian. La imaginación trata de procesar los efectos de este aislamiento, la imposibilidad de rozar nuestros cuerpos, de circular libremente en el espacio público, de ocupar las plazas: el agotamiento por las engorrosas medidas de seguridad con las cuales estamos obligados a convivir; el temor que envuelve los desplazamientos entre naciones y continentes; las consecuencias de la diseminación de los confines entre dimensión pública y privada, tras las permanentes sesiones de Zoom que están abriendo nuestras casas al mundo, en este tiempo suspendido.

El mundo quiere volver a la normalidad. Sin embargo, lo que estamos viviendo no es normal.

En esta condición cruzada por incertidumbres, intentaré esbozar una serie de consideraciones a partir de la literatura como práctica y acción capaz de moldear el mundo, de nombrarlo, de mover la significación para hacer frente a lo que todavía no hemos pensado, mediante imágenes, figuras, relámpagos de sentido que nos ayudan a 'comprender'.

Entre los diferentes ejercicios creativos que podemos experimentar para pensar la pandemia en los territorios de lo simbólico, encuentro muy interesante observar las figuras que habitan el mundo del contagio, en continuidad con las imágenes de prefiguración que, en el territorio de la ficción, han adelantado estos tiempos precarios. Vale la pena reflexionar sobre las audaces tentativas de trazar un mapa del universo del virus, formas aproximadas, imperfectas, ajustadas, vívidas, pulsantes, auténticas, para acercarnos a su verdad. Al mismo tiempo, es sumamente esclarecedor examinar las palabras que 'dicen' el presente en el escenario político e impulsar un movimiento crítico de vigilancia sobre las constelaciones de sentido que irradian. 
Porque nuestra responsabilidad, hoy, es saber cuáles son las palabras que sirven.

A partir de estas consideraciones, resulta evidente que mis preocupaciones no residen en el oficio de rastrear los antecedentes literarios que anticiparon el advenimiento del virus, lo que me parece más productivo es explorar los bordes de estas miradas de anticipación, leer entre fisuras, indagar los mismos actos imaginativos que originaron ciertas escrituras, en toda su potencialidad matérica de generar figuras. Esta actividad en el lenguaje que se alimenta desde los pliegues de la realidad, a partir de sus cortes y silencios, mueve la significación abriendo nuevas posibilidades de lectura de la realidad. Son inauditos espacios de verdad, que fuerzan las mallas de los lenguajes institucionalizados y diseñan alternativas posibles, visiones posibles.

Tengo que confesarles que las incursiones en lo ficcional, que desde pequeña han acompañado mi peculiar experiencia del mundo, en un movimiento horizontal entre los dos planos del existir, la vida real y la vida literaria, en un itinerario de ida y vuelta, han dado un vuelco a partir del octubre 19 y durante todo este largo año. Tengo la sensación rara, pero al mismo tiempo contingente y tangible, que estoy viviendo algo que ya tenía incorporado, inscrito en mis vivencias gracias a la exploración de cierta narrativa. Por un lado, la narrativa de testimonio, directo e indirecto, del Cono Sur, que me ha proporcionado las claves para entender las múltiples formas de ejercicio del poder sobre los cuerpos, los restos de la violencia y del abuso dictatorial que siguen caracterizando los escenarios globales, supuestamente democráticos, y los mecanismos de control biopolítico que ahora, en tiempos de coronavirus, están llegando a su paroxismo; por otro, la escena de escritura de Diamela Eltit que me ha acompañado durante estos últimos ocho años, entrenándome en una práctica de lectura diferente y ofreciéndome una mirada privilegiada sobre las contradicciones y perversiones del capitalismo tardío.

Estas textualidades, como inéditas brújulas, han contribuido a orientarme en mi visión e imaginación de la pandemia. No quiero decir que me hayan ayudado a entenderla mejor, no es este el punto, nunca quise encontrar respuestas que me proporcionaran soluciones prêt-à-porter para descifrar los cambios radicales que afectan nuestra cotidianidad. Dichas lecturas han generado la creación de redes de sentido, vibraciones analógicas capaces de mover el mundo que me rodea y vislumbrar múltiples brechas, aperturas que iluminan zonas, campos del presente aparentemente invisibles.

A partir de estas consideraciones, lo único que puedo hacer desde este escenario que estoy viviendo ${ }^{1}$ es presentarles la serie de imágenes del virus que están per-

1 Milán ha sido uno de los focos del primer contagio, con un índice de mortalidad del 15\% y 16.000 mil muertos frente de una población de 10 millones de habitantes, ahora estamos entrando en una segunda 
manentemente conmigo, figuras que hablan de nuestra circunstancia, desvelando luces y sombras, contradicciones y subversiones.

\section{E1 enemigo invisible}

El campo semántico más convencional con el cual se suele hablar del virus es el escenario de guerra. El Covid19 es un adversario poderoso, invisible, luchador, un enemigo que tenemos que combatir con todas las armas a nuestro alcance. Se trata de una constelación del imaginario que remonta a la dimensión de la batalla, la separación entre lo bueno y lo malo, un imaginario excluyente, habitado por signos de fuerza y destrucción, únicas armas capaces de extinguir el peligro y restaurar el orden.

En realidad, al pensar en la consistencia misma del virus nos damos inmediatamente cuenta de que lo único que pretende hacer es alimentarse, replicarse, sobrevivir, difundir su carga patógena para radicarse en el territorio. No tiene amigos ni enemigos, no quiere desencadenar una guerra, quiere tan solo vivir su vida de virus y vivirla en paz.

Pensarlo como 'enemigo' que tenemos que destruir con las armas 'amigas' de la ciencia significa partir el mundo en dos bandos, a la sombra del contagio, sin explorar con suficiente atención la evidencia del virus: la dimensión de riesgo que conlleva su presencia, ya que la única posibilidad para dominarlo, en los momentos de máxima expansión de su potencial infectivo, es el aislamiento, un aislamiento radical y total. Cuando, en cambio, este mismo potencial baja de intensidad, hay que contenerlo con un capilar control de los contactos. Se trata de una condición que nos implica a todos, sin diferencias ${ }^{2}$ y que supone una actitud de recíproco cuidado y una cultura comunitaria de protección.

Vivir con virus significa asumir que el otro soy yo, que el yo no existe fuera de la relación con el otro. La salud y el bienestar del otro determina y marca mi bienestar.

Aquí tenemos la primera arista, el primer quiebre en el imaginario individualista que refleja la epistemología occidental en la contemporaneidad, los excesos de un yo todopoderoso, hipertrófico, un yo incapaz de pensar el límite, los confines de su individualidad. ${ }^{3}$ Esta debilidad del límite la vemos todos los días en nuestra incapacidad de gestionar el distanciamiento social, que implica, antes que nada,

estación pandémica y todavía no se pueden hacer previsiones.

2 En realidad, las diferencias dependen de las distintas 'respuestas' al contagio, de las heterogéneas formas y medidas puestas en escena para contrarrestar el contagio, no coinciden con la presencia del virus. 3 Como bien afirma Elena Pulcini en su ensayo de 2009, La cura del mondo: paura e responsabilità nel'età globale, (Torino, Bollati Boringhieri). 
una constante atención hacia el otro, una permanente vigilancia ante las presencias que cruzan el espacio público, los múltiples otros ignorados, desapercibidos, expulsados de nuestro régimen escópico. Es la misma debilidad que denuncia la literatura de testimonio: lo que queda de los escenarios dictatoriales es una cultura de la indiferencia, la incapacidad de reaccionar frente a la violencia y al abuso, la insensibilidad frente al dolor de los demás.

Esta inhabilidad de integrar en nuestra mirada los demás cuerpos que habitan nuestra realidad revela la condición de un sujeto que ha perdido sus confines, un sujeto radicalmente soberano, absoluto dominador del mundo, ${ }^{4}$ ciego frente a la demanda del otro.

\section{Los médicos y sus fans}

Otra imagen que me persigue en estos tiempos de pandemia es la icónica representación de la comunidad médica, los súper-héroes en primera línea, el frente de la guerra al virus. No puedo evitar de pensar en Impuesto a la carne, ${ }^{5}$ donde dos mujeres viven encerradas en un hospital por más de doscientos años, bajo los ojos atentos de una plétora de médicos que no logran descubrir el secreto de su historia clínica.

Estos álgidos profesionales, que creen poseer la verdad y el poder para controlar la expansión de la enfermedad, escudriñan sus cuerpos infectos para descubrir el misterio y resolver la imperfección, eliminarla, borrarla para siempre.

Observo la obsesión fanática y burocrática de estos mismos médicos y sus fans todos los días, en su tensión por encontrar la receta perfecta que logre solucionar y sintetizar todos los males, sin poder afirmar la inestabilidad de su visión, porque la prensa quiere escuchar verdades definitivas, no se conforma con aproximadas e hipotéticas conjeturas. La sublime acción en el teatro anatómico, reino de la imaginación y de la creatividad, ha sido suplantada por una estéril batalla entre médicos-burócratas, dominados por la prisión de las estadísticas y la esclavitud de los protocolos.

Del escenario del arte clínico al mundo-hospital, de la medicina como ciencia de la interpretación, de la creación y de la cura, a la medicina como técnica todopoderosa, que mide y registra sus adelantos, ciencia de las infalibles certezas, expuestas a la libre circulación de la pantalla, a las polifacéticas apreciaciones sobre la consistencia de lo que no conocemos, sobre el uso de los presidios clínicos, sobre

4 Tan solo en el prisma de estas reflexiones puedo encontrar una explicación al fenómeno de los 'negacionistas del virus', sujetos soberanos e ilimitados, que ocupan las plazas de las principales ciudades europeas, aumentando los índices del contagio y poniendo a riesgo la vida de sus conciudadanos con la exhibición de su patológico individualismo.

5 Eltit, Diamela, Impuesto a la carne, Santiago de Chile, Seix Barral, 2010. 
la contienda de las vacunas. Los médicos y sus fans, divididos en bandos, encerrados en sus verdades, en sus recetas infalibles. ¿Quién ganará el gordo de la lotería y podrá imponer en todo el mundo su incierto líquido inmunizante?

\section{Asfixia capitalista (el reino de un virus con corona)}

En su tempestivo ensayo sobre la pandemia Donatella Di Cesare6 habla de 'asfixia capitalista' para definir la condición que estamos viviendo. Es interesante la analogía entre la falta de aire y el cansancio como síntoma principal de la enfermedad de coronavirus y la centralidad del acto mismo de respiración en la vida a los tiempos del hipercapitalismo. Una vida que nos deja literalmente sin aliento.

El virus nos ha obligado a tomar una pausa, a parar.

Esta suspensión que todos estamos viviendo, exhibe la evidencia de nuestras existencias aceleradas, siempre y permanentemente en movimiento.

Finalmente, se da una interrupción, una suspensión. Para pensar, para reconectarnos con los ritmos íntimos de nuestra respiración.

Esta misma falta de aire me evoca una epifanía literaria. Esteban, protagonista de El siglo de las luces ${ }^{7}$ logra salir de la enfermedad asmática que lo tiene clavado en una cama desde su nacimiento gracias a las conversaciones con Víctor Hugues y a las amorosas curas de la hermana Sofía. Puede mover su deseo utópico de un mundo mejor gracias a la relación y a la empatía. Afirma su identidad en el abrazo del otro.

Hoy, en cambio, el movimiento entrópico y vacuo que nos domina se interrumpe fatalmente por el virus. Este 'quiebre cinético' representa una especie de desvelamiento y de re-descubrimiento de lo que habíamos olvidado, la consistencia misma de nuestro cuerpo, sus necesidades, su demanda. Un cuerpo colapsado y exhausto que vuelve a percibir la consistencia trágica de sus órganos, símbolo y síntoma de la rehabilitación de un proyecto, de una visión, de una voz.

En la escena que inaugura Sumar, ${ }^{8}$ Aurora Royas y su tocaya marchan hacia la moneda para movilizar su arquitectura rígida. Sobreviven en la marcha apretando sus riñones y conteniendo las sienes, para eludir el dolor causado por la descom-

6 Di Cesare, Donatella. Virus sovrano. L'asfissia capitalista, Torino, Bollati Boringhieri, 2020. No es casual que la filósofa, para leer la actualidad y reflexionar sobre el virus, acuda a la peculiarísima forma de la crónica-ensayo. A través de un contrapunto entre fragmentos en cursivas, en los cuales presenta una serie de vívidos cuadros-testimonios sobre la circunstancia del virus, y el espacio de la especulación, en redondillas, la autora contamina el rigor filosófico de la reflexión con una serie de impresiones, instantáneas de lo vivido, capaces de vehicular, moldear y reorientar el espacio de la especulación.

7 Carpentier, Alejo. El siglo de las luces, Madrid, Cátedra, 1989 [1962].

8 Eltit, Diamela. Sumar, Santiago de Chile, Seix Barral, 2018. 
posición orgánica. Órganos dominados por los ritmos y las lógicas de la nube, que los vigila con su mirada excluyente. El dolor es aquí bien presente, vivo, así como la intención: hacer brecha en un mundo anestesiado donde a los sujetos no se les permite ni un momento de ocio, de reposo, un mundo que encuentra su justificación en los ritmos saturados del trabajo, de la producción neoliberal, álgidos y perpetuos, sin gasto alguno. La marcha inevitable hacia la moneda es cuerpo y voz disidente, presente, que no oculta el dolor y el sufrimiento, que exhibe la precariedad y vulnerabilidad, que afirma una posibilidad alternativa de imaginar el mundo.

Mediante estas sugerencias que transitan en la literatura, mi pregunta es: ¿Esta interrupción que revela la vulnerabilidad de nuestros cuerpos podrá ayudarnos a cambiar el mundo? ¿Podrá permitirnos imaginar una nueva comunidad donde el otro soy yo?

\section{Salida: imaginando el futuro, más allá de la inmunopolítica}

La exhibición al contagio que todos nosotros estamos viviendo ${ }^{9}$ es una arista que nos debería ayudar a repensar al sentido de comunidad rehuyendo las derivas endogámicas representadas por los soberanismos y redescubriendo la importancia de la relación y de la responsabilidad. En estos tiempos de giro inmunopolítico, donde los gobiernos no controlan tan solo la vida de sus ciudadanos sino primariamente su seguridad y protección, es sumamente importante reconsiderar la cuestión de la ciudadanía. Dos las razones: primero, las respuestas inmunitarias, para no comprometer su buen funcionamiento, necesitan cierta exposición al riesgo; la cuestión de las 'defensas' del contagio es una cuestión abierta y ambigua, porque un radicalismo proteccionista podría determinar el debilitamiento de los anticuerpos de nuestro sistema-mundo. Luego, cierto proteccionismo miope que invisibiliza una parte consistente de la población, es decir, la humanidad más precaria, que no tiene acceso a los derechos básicos de seguridad, está comprometiendo radicalmente el buen funcionamiento de las medidas de control frente al virus.

Ha llegado el momento de mirar la realidad con otros ojos y empezar a postular políticas de integración y de rescate de los 'invisibles', de las vidas precarias - migrantes, indocumentados, indigentes, trabajadores informales...- porque nadie está exento del peligro del contagio, que solo se puede contrarrestar gracias

9 Cuando hablo de exhibición al contagio me refiero a la exposición global a la enfermedad que inevitablemente ha alterado el ritmo de todas nuestras vidas y ha transformado drásticamente nuestras formas de habitar el espacio, público y privado. Es importante subrayar, en cambio, que las posibilidades de protegerse del virus no son democráticas ni igualitarias ya que dependen de los distintos contextos geográficos, de sus condiciones sociales y económicas, de sus políticas e ideologías ante la difusión de la pandemia. Más allá de estas consideraciones, lo que no podemos negar es que la presencia del Covid19 ha puesto al descubierto la imposibilidad de una inmunización radical de nuestras vidas ya que todos, en mayor o menor medida, estamos expuestos al riesgo. 
a políticas inclusivas y comunitarias. Cohabitar en territorios complejos significa redescubrir nuestra mutua vulnerabilidad y la receta para vivir juntos y en paz es el respeto y la responsabilidad. Mi deseo persigue este sueño del porvenir, diseñado gracias a la difusión permanente de palabras insumisas y rebeldes, palabras revolucionarias y virales, capaces de fisurar la superficie aséptica del presente e indicarnos un nuevo horizonte. 